\title{
Can Defense Attorneys Detect Forensic Confirmation Bias? \\ Effects on Evidentiary Judgments and Trial Strategies
}

\author{
Nikoleta M. Despodova1,2 \\ Jeff Kukucka3 \\ Alexa Hiley1,2 \\ 1 John Jay College of Criminal Justice \\ 2CUNY Graduate Center \\ 3Towson University
}

This version of the article may not completely replicate the final authoritative version published in Zeitschrift für Psychologie. It is not the version of record and is therefore not suitable for citation. Please do not copy or cite without the permission of the authors.

\section{Author Note}

Nikoleta M. Despodova and Alexa Hiley, Department of Psychology, John Jay College of Criminal Justice and CUNY Graduate Center; Jeff Kukucka, Department of Psychology, Towson University.

Correspondence concerning this article should be addressed to Nikoleta Despodova, Department of Psychology, John Jay College of Criminal Justice, 524 West 59th Street, New York, NY 10019. E-mail: ndespodova@jjay.cuny.edu

This research was supported by a National Science Foundation Graduate Research Fellowship (DGE \#1646736). Any opinions, findings, and conclusions or recommendations expressed in this article are those of the authors and do not necessarily reflect the views of the NSF. We thank Kelly Deegan and Erin Dodson for their assistance with coding. 


\begin{abstract}
Knowledge of task-irrelevant information undermines the probative value of forensic evidence (i.e., forensic confirmation bias). Cross-examination may sensitize jurors to bias-but do attorneys recognize when bias has tainted evidence against their client and adjust their cross-examination strategy accordingly? To address this question, 130 defense attorneys imagined representing a man charged with manslaughter and reviewed a case file that included, among other things, an autopsy report from a medical examiner who was either aware or unaware of their client's recanted confession before ruling the death a homicide. When the examiner knew of the confession, attorneys rated the autopsy as no less probative or reliable, they were no less confident in their client's guilt, and only $46 \%$ raised the possibility of confirmation bias on cross-examination. Our findings suggest that defense attorneys underappreciate the impact of forensic confirmation bias, such that biased forensic testimony would be better avoided via procedural reform.
\end{abstract}

Keywords: forensic science; confirmation bias; attorneys; cross-examination 
Confirmation bias-i.e., the tendency to seek out, select, and interpret information in ways that validate one's pre-existing beliefs - is a ubiquitous phenomenon (Nickerson, 1998). In the forensic sciences, it is now well-known that task-irrelevant knowledge can taint evidentiary judgments (i.e., forensic confirmation bias; Kassin, Dror, \& Kukucka, 2013; see also Cooper \& Meterko, 2019). In one study, for example, fingerprint examiners changed $17 \%$ of their opinions of the same prints after learning of a suspect's alibi or confession (Dror \& Charlton, 2006). Despite this, many examiners resist being blinded to task-irrelevant information (Kukucka, Kassin, Zapf, \& Dror, 2017). As such, they are likely to present bias-tainted opinions in court.

Jurors generally trust forensic evidence (Koehler, 2017; Mitchell \& Garrett, 2019) and fail to discount biased scientific evidence (Chorn \& Kovera, 2019; McAuliff \& Duckworth, 2010). However, Thompson and Scurich (2019) found that jurors rated a forensic examiner as less credible if he admitted on cross-examination that he was aware of task-irrelevant information, compared to when he reported being blind to said information. Thus, cross-examination may help jurors detect and devalue bias-tainted forensic evidence-but only if the defense attorney first recognizes that the evidence is tainted.

Prior work has gauged attorneys' appraisals of eyewitness (Pezdek \& O’Brien, 2014), informant (Key et al., 2018), and confession (Appleby \& McCartin, 2019) evidence. We tested whether attorneys can detect when bias has tainted forensic evidence against their client. Defense attorneys imagined representing a client who confessed to manslaughter but recanted his confession. Each attorney reviewed a case file that included an autopsy report that ruled the death a homicide, written by a medical examiner who was either patently aware or ostensibly unaware of their client's confession. For some, the client's recantation statement also presented a plausible alternative theory for the victim's death. 


\section{Method}

\section{Participants and Design}

We collected e-mail addresses of U.S.-based defense attorneys who were listed as practicing criminal law on various bar association, legal aid, and law firm websites. Attorneys were paid $\$ 30$ to complete the study online. Available funding allowed for the payment of 187 attorneys; data collection was stopped once we reached this number.

Each attorney was randomly assigned to one of four conditions in a 2 (Examiner: Aware vs. Unaware) X 2 (Theory: Absent vs. Present) design. We later excluded data from 57 attorneys (30.5\%) who failed or did not complete a manipulation check, leaving a final sample of $N=130$. A post hoc power analysis using PANGEA indicated that this sample yielded $80 \%$ power to detect $f=0.25$ (Westfall, 2015).

Our final sample was primarily White (83.8\%) and male (67.7\%), with a mean age of 48.10 $(S D=12.70)$. On average, attorneys had 18.91 years of experience $(S D=11.97)$ and estimated having tried 67.61 cases $(S D=68.29)$. Nearly all reported having tried cases in which they doubted the reliability of forensic evidence $(96.9 \%)$ or the reliability of a confession or guilty plea (93.8\%).

\section{Procedure and Materials}

All study materials and data are available on the Open Science Framework at

\section{http://osf.io/fnrts/.}

Police report. Attorneys were asked to imagine representing a man charged with firstdegree manslaughter. First, they read a police report (750 words) which recounted that a 16-yearold boy was found unconscious in his bedroom, was taken to the hospital by his mother and her boyfriend (i.e., their client), and had died. The mother blamed her boyfriend for her son's death, noting that she overheard them arguing in her son's bedroom earlier that night. The boyfriend 
initially denied responsibility_but when interrogated by police, he confessed to having pushed the boy against a brick wall during their argument.

Autopsy report. Then, attorneys read a realistic autopsy report (750 words) in which a medical examiner ruled the death a homicide. In the Aware Examiner condition $(n=60)$, the autopsy report stated that a detective was present for the autopsy and twice stated that the boy's head injury was "consistent with... contact with a brick wall" and thus "congruent with [the boyfriend's] confession." In the Unaware Examiner condition $(n=70)$, the autopsy report did not mention the detective or confession.

Recantation. Next, attorneys read a signed statement from their client (185 words) claiming that police had coerced him to give a false confession (Theory-Absent condition; $n=56$ ). In the Theory-Present condition $(n=74)$, this statement also noted that the boy had recently sustained a serious head injury while playing football and had been complaining of headaches, thus providing a plausible alternative theory for his death.

\section{Dependent Measures}

First, attorneys estimated the likelihoods (0-100\%) that their client was guilty and that they would win the case if it goes to trial. Then, they answered 10 items that gauged their opinions of the confession (five items) and autopsy report (five items) on a scale from 1 (strongly disagree) to 7 (strongly agree; see Electronic Supplementary Materials [ESM] Tables 1-2 for list of items and Tables 10-12 for results of confession items). A factor analysis of the autopsy report items revealed two factors. As a result, we averaged three items pertaining to the autopsy's probative value $(\alpha=$ $.81)$ and two items pertaining to its reliability ( $\alpha=.67$; see Table 1 in ESM for full results).

Attorneys also listed up to five questions that they would ask the medical examiner on cross-examination. Two independent condition-blind coders coded the questions for various 
themes, including whether any of their questions mentioned the examiner's awareness of the confession or potential confirmation bias (95\% agreement; $\kappa=.86, p<.001)$ and/or attacked the examiner's credibility (e.g., allegiance, experience, training; 92\% agreement; $\kappa=.65, p<.001$ ); disagreements were resolved via discussion with the first author (see Table 13 in ESM for descriptions and frequencies of all coded themes). Next, attorneys reported whether they would advise their client to accept a plea bargain if the prosecutor reduced the charge to second-degree manslaughter.

On a new page, a final item asked attorneys if they believed that the medical examiner's "conclusion about the manner of death could have been influenced by external information not available from the autopsy," with options of yes, no, and "I am unable to say."

Manipulation check. Lastly, attorneys were asked if the medical examiner was aware of their client's confession, with options of yes, no, and "such information was not provided." (The latter two options were both considered correct in the Unaware Examiner condition.) We later excluded data from 57 attorneys $(30.5 \%)$ who did not answer $(n=12)$ or incorrectly answered $(n$ $=45)$ this item.

\section{Results}

For each continuous outcome measure, we performed a 2 (Examiner: Unaware vs. Aware) X 2 (Theory: Absent vs. Present) ANOVA (see ESM Tables 4-7). For each categorical outcome measure, we performed a binary logistic regression using Examiner, Theory, and their interaction as predictors (see ESM Tables 8-9). The results of these analyses are summarized in Table 1 and explained below.

Attorneys were largely unaffected by the medical examiner's awareness of their client's confession. Regardless of whether the medical examiner was aware or unaware of the confession, 
attorneys rated the autopsy as equally probative, $p=.827$, and reliable, $p=.070$, believed just as strongly in their client's guilt, $p=.664$ and likelihood of winning the trial, $p=.263$, and were equally likely to recommend a guilty plea, $p=.441$. In contrast, attorneys who read a plausible alternative theory for the victim's death rated the autopsy as less probative, $p=.006$, and reliable, $p=.013$, believed less strongly in their client's guilt, $p=.021$, and were more confident that they would win the trial, $p<.001-$ but were equally likely to recommend a guilty plea, $p=.928$. None of the interactions was significant, $p \mathrm{~s}>.13$.

Collectively, attorneys generated 532 cross-examination questions for the medical examiner $($ Mode $=5 ; 60.8 \%$ ); only six attorneys (4.6\%) generated no such questions. Overall, $26.2 \%$ of attorneys asked at least one bias-related question — and they more often asked such questions of the confession-aware examiner (46.7\%) than the unaware examiner $(8.6 \%), p=.005$. Few attorneys attacked the examiner's credibility (13.1\%); such attacks were more common when an alternative theory was present $(20.3 \%)$ than when it was not $(3.6 \%), p=.036$. No other effects or interactions were significant, $p \mathrm{~s}>.60$.

When explicitly asked, few attorneys believed that the medical examiner's opinion could not have been influenced by non-medical information $(n=3 ; 2.3 \%)$. After excluding these responses, attorneys in the Aware Examiner condition more often answered "yes" to this item than those in the Unaware Examiner condition, $p=.013$. Neither Theory, $p=.914$, nor the interaction, $p=.437$, predicted attorneys' response to this item.

\section{Discussion}

Thompson and Scurich (2019) found that jurors devalued the opinion of a forensic examiner who admitted a priori knowledge of potentially biasing case information. In our study, defense attorneys did not similarly devalue the opinion of a medical examiner with a priori 
knowledge of their client's confession. Whether the examiner was aware or unaware of the confession, attorneys rated his autopsy report as equally probative and reliable and were equally confident in their client's guilt and likely to recommend a guilty plea. These findings echo those of Chorn and Kovera (2019), who found that attorneys rated blind and non-blind IQ tests as being of equal quality. In short, our results suggest that attorneys underappreciate the deleterious effects of confirmation bias on judgments of forensic evidence. It should be noted that the current study was underpowered to detect small effects, and as such, future work should aim to replicate our findings. Nevertheless, in an applied context, a small effect may be of limited practical importance as it would still suggest that many attorneys are insensitive to contextual bias and likely allowing tainted forensic testimony to go unchallenged.

Our manipulation did affect attorneys' trial strategy, such that those who cross-examined a confession-aware examiner more often asked questions pertaining to confirmation bias, and they rarely attacked his credibility. Prior work suggests that this is a sound strategy, insofar as crossexamination has a stronger impact on jurors when it attacks the quality of the evidence rather than the expert's credibility (Austin \& Kovera, 2015; Lieberman, Carrell, Miethe, \& Krauss, 2008). However, only $46.7 \%$ of our attorneys raised the possibility of confirmation bias when crossexamining a confession-aware examiner. Similarly, Chorn and Kovera (2019) found that attorneys were more likely to question the validity of non-blind psychological testing during crossexamination - but still fewer than half of them did so. Therefore, while cross-examination that highlights the potential for confirmation bias can impact juror decision-making (Thompson \& Scurich, 2019), our results suggest that attorneys often fail to raise this issue.

Future research could explore whether attorneys might benefit from training in confirmation bias. Consistent with this idea, $90 \%$ of our attorneys understood that task-irrelevant 
could have impacted the medical examiner's opinion when this possibility was made explicit. Alternatively, the problem of forensic confirmation bias may be better addressed by implementing laboratory procedures_-such as the case manager model (Thompson, 2011) or linear sequential unmasking (Dror et al., 2015) — that shield examiners from potentially biasing influences and thereby prevent biased opinions from being presented in court altogether. 


\section{References}

Appleby, S. C., \& McCartin, H. R. (2019). Effective assistance of counsel? An empirical study of defense attorneys' decision-making in false-confession cases. Cardozo Law Review De Novo, 7, 123-165.

Chorn, J. A., \& Kovera, M. B. (2019). Variations in reliability and validity do not influence judge, attorney, and mock juror decisions about psychological expert evidence. Law and Human Behavior. Advance online publication.

Cooper, G. S., \& Meterko, V. (2019). Cognitive bias research in forensic science: A systematic review. Forensic Science International, 297, 35-46.

Dror, I. E., \& Charlton, D. (2006). Why experts make errors. Journal of Forensic Identification, $56,600-616$.

Dror, I. E., Thompson, W. C., Meissner, C. A., Kornfield, I., Krane, D., Saks, M., \& Risinger, M. (2015). Context management toolbox: A linear sequential unmasking (LSU) approach for minimizing cognitive bias in forensic decision making. Journal of Forensic Sciences, 60, 1111-1112.

Kassin, S. M., Dror, I. E., \& Kukucka, J. (2013). The forensic confirmation bias: Problems, perspectives, and proposed solutions. Journal of Applied Research in Memory and Cognition, 2, 42-52.

Key, K. N., Neuschatz, J. S., Bornstein, B. H., Wetmore, S. A., Luecht, K. M., Dellapaolera, K. S., \& Quinlivan, D. S. (2018). Beliefs about secondary confession evidence: A survey of laypeople and defense attorneys. Psychology, Crime \& Law, 24, 1-13.

Koehler, J. J. (2017). Intuitive error rate estimates for the forensic sciences. Jurimetrics, 57, 153168. 
Kukucka, J., Kassin, S. M., Zapf, P. A., \& Dror, I. E. (2017). Cognitive bias and blindness: A global survey of forensic science examiners. Journal of Applied Research in Memory and Cognition, 6, 452-459.

Lieberman, J. D., Carrell, C. A., Miethe, T. D., \& Krauss, D. A. (2008). Gold versus platinum: Do jurors recognize the superiority and limitations of DNA evidence compared to other types of forensic evidence? Psychology, Public Policy, and Law, 14, 27-62.

McAuliff, B. D., \& Duckworth, T. D. (2010). I spy with my little eye: Jurors' detection of internal validity threats in expert evidence. Law and Human Behavior, 34, 489-500.

Mitchell, G., \& Garrett, B. L. (2019). The impact of proficiency testing information and error aversions on the weight given to fingerprint evidence. Behavioral Sciences and the Law, 37, 195-210.

Nickerson, R. S. (1998). Confirmation bias: A ubiquitous phenomenon in many guises. Review of General Psychology, 2, 175-220.

Pezdek, K., \& O'Brien, M. (2014). Plea bargaining and appraisals of eyewitness evidence by prosecutors and defense attorneys. Psychology, Crime \& Law, 20, 222-241.

Thompson, W. C. (2011). What role should investigative facts play in the evaluation of scientific evidence? Australian Journal of Forensic Sciences, 43, 123-134.

Thompson, W. C., \& Scurich, N. (2019). How cross-examination on subjectivity and bias affects jurors' evaluations of forensic science evidence. Journal of Forensic Sciences, 64, 13791388.

Westfall, J. (2015). PANGEA: Power analysis for general ANOVA designs. Retrieved from http://jakewestfall.org/publications/pangea.pdf. 
Table 1

Attorney Responses (M [SE] or \% [SE]) as a Function of Examiner (Unaware vs. Aware) and Theory (Absent vs. Present)

\begin{tabular}{|c|c|c|c|c|c|c|c|}
\hline & \multicolumn{2}{|c|}{ Unaware Examiner } & \multicolumn{2}{|c|}{ Aware Examiner } & \multirow[b]{2}{*}{ ESExaminer } & \multirow[b]{2}{*}{ ESTheory } & \multirow[b]{2}{*}{ ESInteraction } \\
\hline & $\begin{array}{l}\text { Theory } \\
\text { Absent }\end{array}$ & $\begin{array}{l}\text { Theory } \\
\text { Present }\end{array}$ & $\begin{array}{l}\text { Theory } \\
\text { Absent }\end{array}$ & $\begin{array}{l}\text { Theory } \\
\text { Present }\end{array}$ & & & \\
\hline Likelihood of Guilt (0-100) & $\begin{array}{l}61.00 \\
(5.16)\end{array}$ & $\begin{array}{l}54.03 \\
(3.78)\end{array}$ & $\begin{array}{l}62.35 \\
(4.73)\end{array}$ & $\begin{array}{l}48.88 \\
(3.76)\end{array}$ & $\begin{array}{c}0.09 \\
{[-0.25,0.44]}\end{array}$ & $\begin{array}{c}0.41 * \\
{[0.06,0.76]}\end{array}$ & $\begin{array}{c}0.00 \\
{[0.00,0.04]}\end{array}$ \\
\hline Likelihood of Winning Case (0-100) & $\begin{array}{l}35.17 \\
(4.06)\end{array}$ & $\begin{array}{l}50.48 \\
(3.57)\end{array}$ & $\begin{array}{l}32.04 \\
(4.20)\end{array}$ & $\begin{array}{l}44.94 \\
(3.47)\end{array}$ & $\begin{array}{c}0.21 \\
{[-0.14,0.55]}\end{array}$ & $\begin{array}{c}0.66^{* * *} * \\
{[0.30,1.02]}\end{array}$ & $\begin{array}{c}0.00 \\
{[0.00,0.03]}\end{array}$ \\
\hline Probative Value of Autopsy (1-7) & $\begin{array}{l}4.13 \\
(.31)\end{array}$ & $\begin{array}{l}3.39 \\
(.23)\end{array}$ & $\begin{array}{l}4.18 \\
(.30)\end{array}$ & $\begin{array}{l}3.46 \\
(.21)\end{array}$ & $\begin{array}{c}0.04 \\
{[-0.30,0.39]}\end{array}$ & $\begin{array}{c}0.50 * * \\
{[0.15,0.85]}\end{array}$ & $\begin{array}{c}0.00 \\
{[0.00,0.00]}\end{array}$ \\
\hline Reliability of Autopsy (1-7) & $\begin{array}{l}4.50 \\
(.16)\end{array}$ & $\begin{array}{l}4.13 \\
(.17)\end{array}$ & $\begin{array}{l}4.27 \\
(.27)\end{array}$ & $\begin{array}{l}3.59 \\
(.23)\end{array}$ & $\begin{array}{c}0.33 \\
{[-0.01,0.68]}\end{array}$ & $\begin{array}{c}0.43 * \\
{[0.08,0.78]}\end{array}$ & $\begin{array}{c}0.00 \\
{[0.00,0.04]}\end{array}$ \\
\hline $\begin{array}{r}\text { Would you advise client to accept } \\
\text { plea bargain? }(\%)\end{array}$ & $\begin{array}{l}55.17 \\
(4.47)\end{array}$ & $\begin{array}{l}54.05 \\
(4.48)\end{array}$ & $\begin{array}{l}65.39 \\
(4.27)\end{array}$ & $\begin{array}{l}37.50 \\
(4.35)\end{array}$ & $\begin{array}{c}1.54 \\
{[0.52,4.57]}\end{array}$ & $\begin{array}{c}0.96 \\
{[0.36,2.54]}\end{array}$ & $\begin{array}{c}0.33 \\
{[0.08,1.43]}\end{array}$ \\
\hline $\begin{array}{r}\text { Would attorney ask ME about } \\
\text { bias/confession? (\%) }\end{array}$ & $\begin{array}{l}10.00 \\
(2.63)\end{array}$ & $\begin{array}{l}7.50 \\
(2.31)\end{array}$ & $\begin{array}{l}46.15 \\
(4.37)\end{array}$ & $\begin{array}{l}47.06 \\
(4.38)\end{array}$ & $\begin{array}{c}7.71 * * \\
{[1.86,31.93]}\end{array}$ & $\begin{array}{c}0.73 \\
{[0.14,3.90]}\end{array}$ & $\begin{array}{c}1.42 \\
{[0.20,10.12]}\end{array}$ \\
\hline $\begin{array}{r}\text { Would attorney attack ME's } \\
\text { credibility? (\%) }\end{array}$ & $\begin{array}{c}3.33 \\
(1.57)\end{array}$ & $\begin{array}{l}25.00 \\
(3.80)\end{array}$ & $\begin{array}{l}3.85 \\
(1.69)\end{array}$ & $\begin{array}{l}14.71 \\
(3.11)\end{array}$ & $\begin{array}{c}1.16 \\
{[0.07,19.52]}\end{array}$ & $\begin{array}{c}9.67 * \\
{[1.16,80.38]}\end{array}$ & $\begin{array}{c}0.45 \\
{[0.02,9.54]}\end{array}$ \\
\hline $\begin{array}{l}\text { Could non-medical info have } \\
\text { influenced ME's opinion? }(\%)\end{array}$ & $\begin{array}{l}55.17 \\
(4.41)\end{array}$ & $\begin{array}{l}53.85 \\
(4.42)\end{array}$ & $\begin{array}{l}88.00 \\
(2.88)\end{array}$ & $\begin{array}{l}94.12 \\
(2.09)\end{array}$ & $\begin{array}{c}5.96^{*} \\
{[1.45,24.43]}\end{array}$ & $\begin{array}{c}0.95 \\
{[0.36,2.49]}\end{array}$ & $\begin{array}{c}2.30 \\
{[0.28,18.88]}\end{array}$ \\
\hline
\end{tabular}

Note. ${ }^{*} p<.05 .{ }^{*} p<.01 . * * * p<.001 . \mathrm{ES}=$ effect size. $\mathrm{ME}=$ medical examiner. For probative value and reliability, higher scores indicate stronger belief in the autopsy's probative value or reliability. For continuous variables, the table reports $d$ [95\% CI] for main effects and $\eta_{2 p}[90 \% \mathrm{CI}]$ for interactions. For categorical variables, the table reports OR $[95 \% \mathrm{CI}]$. 